\title{
Selected Problems of Microgeneration Development in Poland
}

\author{
Waldemar Dolega ${ }^{1}$
}

\begin{abstract}
This paper describes selected problems of current development of microgeneration in Poland. Analysis of microgeneration in Poland is shown. Technical, economical and market potential of microgeneration in Poland is defined. Analysis and assessment of microgeneration in Poland in technical, economical and environmental aspects is made. Perspectives of development of microgeneration up to 2020 in context of the implementation of the EU's " 3 x 20\%" climate package by Poland and national quantitative target for RES development by year 2020 are described. Selected technical, economic and legal problems of development of microgeneration in Poland are shown. Conclusions contain analysis of barriers and perspectives of development of microgeneration in Poland in the future.
\end{abstract}

Keywords

Microgeneration, prosumer, development.

\section{Introduction}

The rational use of energy from renewable sources is a major element of the sustainable development of Poland, bringing about notable environmental and energy effects. It is important that renewable energy sources are used for electricity supply, room heating and domestic hot water preparation in single-family houses and apartment buildings. Such solutions contribute to, among other things, a reduction in energy demand, a reduction in building operating expenditures, an improvement in the environmental standard of living, and so on. Their mass use improves the local energy balance, saves energy fuels, reduces the emission of $\mathrm{CO}_{2}, \mathrm{SO}_{2}, \mathrm{NO}_{\mathrm{x}}$ and other pollutants into the air and lowers the heat and electricity acquisition costs. Of key importance here is the development of prosumer microfacilities. It is also important in context of two main Polish national 2020 targets: $15 \%$ share of energy generated from renewable energy sources (RES) in the total primary energy and $\mathrm{CO}_{2}$ emissions reduction by $20 \%$ [1].

\section{Current and future state of RES installations in Poland}

The RES in Poland comprise different types of distributed systems: biomass systems, biogas systems, wind power plants, hydroelectric power plants and photovoltaic systems, The systems differ greatly with regard to their equipment, the characteristics of their units, and their technologies.

The pace of development of the RES sector and especially the wind power industry in Poland has accelerated in recent years. But growth rate of RES in Poland are still limited. It stem from a number of development barriers, among which the most significant

\footnotetext{
${ }^{1}$ Department of Electrical Power Engineering,

Faculty of Electrical Engineering,

Wroclaw University of Technology

50-370 Wroclaw, Poland

Wybrzeze Wyspianskiego 27

(e-mail: Waldemar.dolega@pwr.edu.pl)
}

This is an Open Access article distributed in accordance with the Creative Commons Attribution Non Commercial (CC-BY-NC-ND 4.0) license, which permits others to copy or share the article, provided original work is properly cited and that this is not done for commercial purposes. Users may not remix, transform, or build upon the material and may not distribute the modified material (http://creativecommons.org/licenses/by-nc/4.0/) 
is the condition of the power grid leading to increasing problems with grid connection. Other factors hindering the development include prolonged procedures related to spatial planning and environmental impact assessments [2].

At the end of 2014 the total RES installed capacity in Poland amounted to $6029 \mathrm{MW}$. It was $15.8 \%$ share of total installed capacity. Total installed capacity of RES and total amount of produced electricity in RES in years 2010-2014 in Poland are shown in Table 1.

As regards wind power, large increase in installed capacity and in energy production has been observed in the past years. It stems from high technological maturity of wind power, increased output of individual wind turbines and wind farms and cost competitiveness compared to other renewable technologies used in Poland to produce electricity [2]. Wind energy is a leader in the production of "green" electricity in Poland and is also the fastest developing renewable energy source in Poland. It is a similar phenomenon like in the Europe, although at a much lesser scale. The wind power is the leading and prospective technology for combating global warming.

Growth rates in the RES sector and electricity production from RES accelerated significantly since 2010. However, the considerable increase in the percentage data is still attributable to the low level of market development in absolute numbers. RES sector in Poland is still at early stage of development. Now, there are 2038 licensed RES installations operating nationwide (196 - biomass, 36 - biogas, 931 - wind, 756 - water and 119 - photovoltaic) [3].

Currently, the RES sector has significant further growth potential. The growing number of issued permits and projects under execution ensure high pace of RES development up to 2020 [3].

The national RES sector has a very significant development potential. An important issue demonstrating the market potential of the RES sector in Poland is the presence of leading European and world's energy groups and producers of devices and equipment for RES. Significant interest from foreign companies and their activity make the Polish RES sector dynamic. The conditions and development perspectives of the RES sector in Poland are very good especially in area of wind power. From point of view of renewable energy country attractiveness indices, Poland was classified on the fourteenth position. Among the EU-27 Poland was ranked the ninth, whereas among new EU Member States and countries in Central and Eastern Europe it was first [4].

Planned by government total RES installed capacity and total yearly amount of produced electricity in RES at the end of 2020 amount to respectively $9380 \mathrm{MW}$ and $27331 \mathrm{GWh}$ [5]. It let reduce of $\mathrm{CO}_{2}$ emissions on level of $22680 \mathrm{kMg} /$ year [5].

Intensive RES development in Poland requires solutions of many technical, economic and legal problems which put a number of hindrances and formal, legal and technical development barriers. Many of them are connected with fast changing the legal environment. The most significant are legal procedures related to spatial planning and environmental impact assessments and problems with grid connection.

Presented subject matter of RES installations in Poland concern mainly large, medium and small installations. Microgeneration connected with prosumer energy sector has a special additional problems which are described in next chapters of paper.

Table 1 Cumulative power installation and electric energy production in RES in years 2010-2014 in Poland [3]

\begin{tabular}{|l|l|c|c|c|c|c|}
\hline & Source & 2010 & 2011 & 2012 & 2013 & 2014 \\
\hline Nominal power [MW] & Biogas & 82.88 & 103.49 & 131.25 & 162.24 & 188.55 \\
\hline $\begin{array}{l}\text { Amount of produced electricity } \\
{[\mathrm{MWh}] \text { in year }}\end{array}$ & Biogas & 363596 & 430537 & 529384 & 665143 & 782744 \\
\hline Nominal power [MW] & Biomass & 356.19 & 409.68 & 820.70 & 986.87 & 1008.24 \\
\hline $\begin{array}{l}\text { Amount of produced electricity } \\
{[\mathrm{MWh} \text { in year }}\end{array}$ & Biomass & 635635 & 1101189 & 2208508 & 3281775 & 3013355 \\
\hline Nominal power [MW] & Wind & 1180.27 & 1616.36 & 2496.75 & 3389.54 & 3833.83 \\
\hline $\begin{array}{l}\text { Amount of produced electricity } \\
{[\mathrm{MWh} \text { in year }}\end{array}$ & Wind & 1823297 & 3128673 & 4612894 & 6077358 & 7624018 \\
\hline Nominal power [MW] & Water & 937.04 & 951.39 & 966.10 & 970.13 & 977.01 \\
\hline $\begin{array}{l}\text { Amount of produced electricity } \\
{[\mathrm{MWh} \text { in year }}\end{array}$ & Water & 2922052 & 2316833 & 2031725 & 2439275 & 2180417 \\
\hline Nominal power [MW] & Photo- & 0.03 & 1.12 & 1.29 & 1.90 & 21.00 \\
\hline
\end{tabular}


Selected Problems of Microgeneration Development in Poland

\begin{tabular}{|l|l|c|c|c|c|c|}
\hline & voltaic & & & & & \\
\hline $\begin{array}{l}\text { Amount of produced electricity } \\
{[\mathrm{MWh} \text { in year }}\end{array}$ & $\begin{array}{l}\text { Photo- } \\
\text { voltaic }\end{array}$ & 2 & 178 & 1178 & 1419 & 3848 \\
\hline Nominal power [MW] & Total & 2556,41 & 3082.04 & 4416.09 & 5510.68 & 6028.63 \\
\hline $\begin{array}{l}\text { Amount of produced electricity } \\
{[\mathrm{MWh} \text { in year }}\end{array}$ & Total & 5744582 & 6977410 & 9383689 & 12464970 & 13604382 \\
\hline
\end{tabular}

\section{Role of prosumers on local energy markets}

The prosumer facilities used for electricity generation are mainly photovoltaic panels, household wind turbines, micro hydro-plants and CHP generators. Photovoltaic energy sources are the primary type of prosumer facilities in the EU countries [6]. Considering the Polish regulations regarding the construction business [7], and the availability of technologies, one can expect that similarly as in other EU countries, also in Poland photovoltaic energy sources will predominate in microgeneration.

Prosumers, i.e. producers who generate electricity and use it for their own needs in households, will play an increasingly greater role on local energy markets as well as in many aspects and elements of the functioning and operation of the electric power system and in planning its development at different levels (especially at the local level administered by the distribution system operator (DSO))[8]. The scale of this influence will depend on the number of prosumers and it may become critical for environmental and local electricity supply security.

As regards grid infrastructure development planning, the role of prosumers on local energy markets will to a large extent depend on the development of prosumer microfacilities [8]. In the case of standard microfacilities, this role will be passive - their influence on the market will stem from the reduction in electricity uptake from the electric power networks. Whereas in the case of a significant development of microfacilities equipped with an energy storage device, control devices and devices for communicating with DSO, proper measures connected with, e.g., the balancing of the grid and the planning of its development will be necessary. At the moment the constraint is the relatively low number of prosumers in Poland [6]. At the end of 2014 the number of prosumers amounted to 576 and the total installed capacity of prosumer facilities and the total amount of produced electricity by prosumers in year recpectively amounted to $2832.80 \mathrm{~kW}$ and $508888 \mathrm{kWh}$ [3].

\section{Development of prosumer energy sector}

The development of the prosumer energy sector in Poland is constrained by several factors. The main constraints are procedural and economic.

The procedural constraints were to a significant extent removed by the 26 July 2013 amendment to the Energy Law [9] - key law act in Poland in RES area, removing the existing barriers (such as the necessity to conduct business activity, to licence this activity and to issue grid connection terms and conditions) and introducing regulations making it easier for a small renewable energy producer intending to consume most of this energy for his/her own needs to connect the generation facility to the distribution grid, while removing the charges for such a connection and minimizing the formal procedures.

The above amendment to the Energy Law introduces, among other things, two new definitions relating to the notion of the "prosumer":

- a microfacility - a renewable source of energy, with the total installed electric capacity not larger than 40 $\mathrm{kW}$, connected to an electric power network with a rated voltage lower than $110 \mathrm{kV}$, or with the total installed thermal capacity not higher than $120 \mathrm{~kW}$;

- a small facility - a renewable source of energy, with a total installed electric capacity larger than $40 \mathrm{~kW}$ but not larger than $200 \mathrm{~kW}$, connected to an electric power network with a rated voltage lower than 110 $\mathrm{kV}$, or with the total installed thermal power capacity larger than $120 \mathrm{~kW}$ but not larger than $600 \mathrm{~kW}$ [9].

The Act specifies that no charge is levied for the connection of a microfacility to a distribution network. Moreover, when the entity applying for the connection of a microfacility to a distribution network is connected as the end user to the network and the installed capacity of the microfacility for the connection of which the entity is applying is not larger than the one specified in the issued connection terms and conditions, the connection to the network takes place solely on the basis of the microfacility connection application submitted to the electric power firm to whose network the microfacility is to be connected after the installation of proper protection systems and a measuring-billing system. The cost of installing the protection systems and the measuring- 
billing system is borne by the DSO [9]. In addition, it is specified that this seller is obliged to buy the electric energy generated in the microfacility connected to the distribution network located in the territory comprising the seller's official operating area, and offered for sale. The energy is purchased at a price amounting to $80 \%$ of the average electricity sale price in the preceding calendar year (the competitive market price) [9].

The economic constraints have a principal effect on the number of prosumers in Poland. The constraints stem from the fact that no grid parity electricity price level (the price of the energy generated by one's own energy source should be equal to the price of the electricity bought from the grid) has been reached yet in Poland by the majority of the small-scale technologies used in prosumer facilities. This is due to the less mature microfacility market and the lower electricity prices for households than in the old EU countries (UE-15) [6]. So far the smallest renewable energy sources used in prosumer microfacilities have not been granted preferential treatment or dedicated support [10].

Planned by government total installed capacity of microgeneration and total yearly amount of produced electricity in prosumer facilities at the end of 2020 amount to respectively $1937 \mathrm{MW}$ and $2931 \mathrm{GWh}$ [5].

\section{Prosumer energy sector support systems}

The experiences regarding the development of electric energy microgeneration in different EU countries (Germany, Italy, the UK) indicate that most of the electricity generated in microfacilities is consumed on the spot by the prosumer [6]. They also indicate that with proper support the prosumer energy sector can develop at a fast rate, which is important for, e.g., reducing the maximum power demand. In the nearest future (20162017) this may apply to the National Electric Power System [8].

In order to reach one of the primary objectives of the Polish energy policy, e.g., the share of $15 \%$ of energy from renewable sources in the gross final energy in 2020, it is necessary to increase the percentage of prosumer microfacilities in the national energy mix [5]. The foreign experiences mentioned above as well as the domestic experience in the field of solar collectors show that it is definitely possible to quickly develop prosumer facilities for the production of electricity. But this requires the launching of dedicated support systems. Otherwise, the development of prosumer microfacilities will be delayed by several or as many as twenty years. due to the reaching of grid parity by a large part of the prosumer technologies.

The best mechanism to support the development of prosumer microfacilities is to provide support at the investment stage without any additional charges on the generated energy. This solution offers an incentive to prosumers to maximize the consumption of electricity generated in microfacilities for their own needs. Thanks to the reduction in the energy drawn from the electric power grid by prosumers the development of prosumer microfacilities and the proper functioning of the distribution network will be ensured and the EU goals (e.g. $\mathrm{CO}_{2}$ emission reduction and the proper share of energy from renewable sources) stemming from the Climate and Energy Package will be achieved [2]. The support of prosumers through various subsidies to the energy generated in a microfacility and introduced into the grid may lead to all kinds of improper prosumer behaviours, such as the desire to resell as much of the energy generated in a microfacility as possible, and not to consume it for one's own needs.

At the moment the following measures are of key importance for the development of microfacilities:

- to provide funds (from the EU funds for the years 2014-20) for the support of prosumer microfacilities at the national, regional and local levels,

- to launch other funds, e.g. through the National Fund for Environmental Protection and Water Management (NFEP\&WM).

The different aspects connected with the use of renewable energy sources in construction, including the domestic regulations, programmes and means of support are presented in, e.g., [11]. In the latter publication one can find an analysis of the very dynamic development of solar collectors in the years 2010-2012, resulting from the implementation of the nationwide programme of subsidies to the purchase and installation of solar collectors by natural persons and housing cooperatives, by the National Fund for Environmental Protection and Water Management.

Now, major importance for development of microgeneration in Poland has the Prosument Programme being carried out by the National Fund for Environmental Protection and Water Management, which has great experience and offers practical solutions in this field.

\section{Technical aspects of microgeneration development}

The proper operation of the distribution network and of the microfacilities as well as the security of supply, the continuity of supply and the high quality of the energy 
supplied to consumers require, among other things, proper principles of connecting microfacilities to the electric power grid [4].

The connection of a microfacility to the grid on the basis of solely an application, without specifying the technical principles (e.g. connection conditions or criteria) and without a possibility of refusing (in justified cases) a connection, may result in, e.g., damage to the other consumers' equipment, grid overloads and the automatic cutout of the entire circuits to which the microfacilities are connected [6]. Consequently, instead of receiving electricity from microfacilities the distribution system operators may have to deal with increasingly frequent cutouts or overloads of LV distribution lines caused by the operation of prosumer microfacilities. Such a danger can also arise in the case of high saturation of the system with microfacilities, i.e. at an advanced stage in the development of the prosumer energy sector. Once the possibilities of connection to the electric power grid are exhausted, DSO should have the right to refuse the connection of another microfacility and to set a date on which such a connection will be possible (after the grid structure is modernized and expanded).

A substantial increase in the number of microfacilities, particularly when their connection on the basis of solely an application is still continued (which is desirable from the prosumer facility market point of view), may cause serious problems with energy balancing in electric power networks, deterioration in the energy quality parameters and an increase in the number of automatic disconnections of supply to consumers due to overloads in the LV networks. Therefore distribution system operators need to take proper steps in order not only to foresee the above phenomena, but also to protect the electric power system against them. The optimal solution would be to equip such microfacilities with their own energy storage devices.

The fast development of the prosumer energy sector and its secure management can be significantly aided by the intelligent power system technology. The connection of a prosumer to the power grid entails the accounting of the energy flow in two directions: to and from the grid. Transmission charge rates may differ depending on the direction, the time of the day and even the situation on the market (dynamic tariffs). Only intelligent meters can meet such requirements.

\section{Conclusion}

The development of microgeneration is vital to reaching the energy policy objectives for $2020-15 \%$ share of energy generated from renewable energy sources in the total primary energy and $\mathrm{CO}_{2}$ emissions reduction by $20 \%$ and so it should take priority in the development of the national economy.

The potential for the development of the prosumer energy sector is very high. There are about $6 \mathrm{M}$ of residential buildings in Poland, 5.5 $\mathrm{M}$ of this number are single-family houses. This represents the approximate maximum number of potential prosumer facilities. The introduced support systems will to a considerable extent determine the degree to which this potential will be used.

The prosumer energy sector can intensively develop if proper funds are provided to support the development of prosumer microfacilities at the national, regional and local levels and if proper programmes are launched. The Prosument Programme being carried out by the National Fund for Environmental Protection and Water Management, which has great experience and offers practical solutions in this field, is of major importance. The implementation of the previous NFEP\&WM nationwide programme of subsidies to the purchase and installation of solar collectors by natural persons and housing cooperatives contributed to the very dynamic development of solar energy sector in the years 20102014.

\section{References}

[1] Announcement of Ministry of Economy from 21.12.2009 in a matter of the national energy policy up to 2030 (Monitor of Poland of 2010 No.2, Item 11). (In Polish)

[2] Wind energy in Poland. IDZP, TPA Horwath. Report, November 2013. URL: http://www.paiz.gov.pl/ files/?id_plik=21375.

[3] Activity of the President of Energy Regulatory Office in 2014. Report, The Energy Regulatory Office, Warsaw, 2015. URL: http://www.ure.gov.pl/ pl/urzad/informacje-ogolne/ sprawozdania/ 2916, Sprawozdania.html. (In Polish)

[4] Dolega, W. "Selected problems of RES development in Poland," 8-th International Conference on Deregulated Electricity Market Issues in SouthEastern Europe DEMSEE 2013, Cavtat, Croatia, Sep. 24-25, 2013, paper 36.

[5] National renewable energy action plan for Poland. Ministry of Economy, Warsaw 2010. (In Polish)

[6] Zmijewski, K. and others, "Prosumer in smart electric power grid". Report, E. Kwiatkowski Institute, Warsaw, 2013. (In Polish) 
W. Dolega
Selected Problems of Microgeneration Development in Poland

[7] Act of 7 July 1994 - Construction Law (Journal of Laws of 1994 No.89, Item 414, with later changes). (In Polish)

[8] Dolega, W., "The planning of electric power network infrastructure development with regard to energy supply security and environmental safety," Published House of the Wroclaw University of Technology, Wroclaw, pp. 127-151. 2013.

[9] Act of 10 April 1997 - The Energy Law (Journal of Laws of 2006 No.89, Item 625, with later changes). (In Polish)

[10]Dolega, W. "Analysis and assessment of support mechanisms for the promotion of renewable energy sources - case study Poland," 6-th International Workshop on Deregulated Electricity Market Issues in South-Eastern Europe DEMSEE 2011, Bled, Slovenia, Sep. 20-21, 2011. Zalozba FE in FRI, paper 087.

[11]Dolega, W. "Law and economic aspects of utilisation of renewable energy sources in construction," Polityka Energetyczna - Energy Policy Journal, 15(1), pp. 77-86. 2012.k 